is perhaps scarcely surprising that there grew up around him a school largely devoted to enzyme chemistry in many varied aspects-the machinery of the cell. The extent to which Sir Frederick's view of the scope of biochemistry is now accepted is the measure of his work, but it is only those who have been privileged to study under his influence in the years during which he has directed his school who can appreciate fully what the subject owes to him. His influence on those who worked with him, even for a short time, was always remarkable. He had the precious gift of illuminating discussions. This was especially evident during 'tea club' meetings of the Department, at which papers were read describing work in progress. Sometimes the audience listened to work which appeared dull and even unimportant, but as soon as the Professor opened the discussion the scene changed, the scattered threads made a pattern and the implication of the work took on a new value. In the experience of his pupils this gift is unique. To be associated with Sir Frederick has resulted for many in a certain libera. tion of the mind which enabled them then and later to approach problems with a new confidence, problems which, but for him, they would have discarded. Many lesser men freeze and inhibit; he thaws and liberates.

\section{The Gas Research Board}

Dr. James GrIEve KING, superintendent of the Fuel Research Station, East Greenwich, has been appointed director of the Gas Research Board. Dr. King, who is fifty-one years of age, is a native of Scotland, where he started his career as assistant to Prof. T. Gray at the Royal Technical College, flasgow, during 1912-1914. During the War of 1914-1918, he was chemist and finally departmental superintendent of Nobel's Explosives Co., Ltd. Dr. King joined the staff of the Fuel Research Station as research chemist in 1919 , becoming chief chemist in 1920 and superintendent in 1941. He has a very wide experience in the field of fuel technology. The long list of his published researches includes a number of papers presented, either alone or in collaboration, at autumn research meetings of the Institution of Gas Engineers. His joint paper with the late Eng.Captain J. F. Shaw, on "Reeent Experiments at the Fuel Research Station upon Production of Solid Smokeless Fuel", was awarded the Institution Gold Medal for 1934, and his joint paper with Mr. James Jamieson, on "Products obtained by the Carboniza. tion of Scottish Cannel in Continuous Vertical Retorts", was awarded the H. E. Jones London Medal of the Institution in 1936. Among his earliest publications was a joint paper, with Prof. T. Gray, on "The Assay of Coal for Carbonization Purposes", which described the now classic Gray-King apparatus.

Dr. Frederick James Dent has been appointed joint assistant director of the Board. Dr. Dent is thirty-seven years of age and is a native of Leeds. $\mathrm{He}$ obtained the B.Sc. degree in gas engineering at the University of Leeds in 1926, the Ph.D. degree in 1929, and was awarded the D.Sc. degree in 1939 . $\mathrm{He}$ won the Arthur Smithells Research Scholarship and the Le Blanc Medal in 1927, and was the Institution Gas Research Fellow for 1927-1929. Since 1929 he has been a research chemist of the Institution of Gas Engineers and more recently of the Gas Research Board, engaged upon investigations for the Joint Research Committee. Dr. Dent has also given special lectures on water gas manufacture in the University of Leeds.

\section{Newton's Library}

Messrs. Henry Sotheran, Litd., of Sackville Street, W.1, are offering for sale the hitherto undispersed portion of Newton's library. The collection includes several books of great personal and historical interest in connexion with their former owner, the most important being copies of the first and second editions of the "Principia" and Isaac Barrow's edition of Euclid. According to the vendor's notice of the sale, the first two contain a number of corrections, cancellations and additions in Newton's handwriting. These copies formed the basis of the new editions and, judging from the fact that the title page of the copy of the first edition was revised, it seems possible that this copy was intended for the printer. The edition of Barrow's "Euclidis Elementa" contains MS. notes in Newton's handwriting, mostly giving the propositions in algebraic notation. Books $\mathrm{V}, \mathrm{VI}$ and $\mathrm{X}$ received his special attention. It seems likely that this copy was actually used by Newton in his undergraduate days at Trinity College, Cambridge, when he had come to appreciate Euclid. Other items of interest include a copy of the second English translation of Euclid-that made by Captain Rudd, engineer-in-chief to the Royalist forces, published in 1651. It may be the copy of which Brewster states that Newton "threw it aside as a 'trifling book'". There are also copies of Barrow's "Lectiones Optica" (1669) and Huygen's "Traité de la Lumière" (1690), each of which contains an inscription by Newton stating that it was a presentation copy from the author. It is well known that Newton corrected the proofs of the former and made several corrections and additions. It is a surprising and unexplained fact that although Newton by this time was almost certainly in possession of his theory of colours, he did not correct Barrow's ideas on the subject.

The books are offered for sale in two lots, one of them consisting of Barrow's "Euclidis Elementa" and the other of 858 items. It is to be hoped that this interesting collection will be disposed of as a whole and that it will remain in Great Britain. It represents all that is left of the 1,896 books which formed Newton's library when he died in 1727 . The complete library was then purchased for $£ 300$ by John Huggins, warden of the Fleet Prison, a near neighbour of Newton's. Huggins' receipt for the $£ 300$ and a complete list of the books is now in the British Museum. He presented them to his son, who pasted his bookplate, bearing the inscription "Revd. Carol. Huggins, Rector of Chinner, in Com. Oxon.", in all his books. They were afterwards sold for $£ 400$ to Dr. James Musgrave, who succeeded Charles Huggins at Chinnor. He pasted his bookplate over that of Charles Huggins, his plate bearing the Musgrave arms and the motto "Philosophemur". The books then disappeared for about 170 years until bundles of them, including one of 200 , were sold at rubbish prices at the sale of Thame Park (belonging to the Musgrave family) in 1920. Barrow's Euclid was one of the items disposed of on this occasion. It is these books which are occasionally found in the secondhand bookshops, though many have gone to the United States and, it is feared, many have been treated as waste paper.

The remainder of the library was discovered in 1928 at Barnsley Park (which also belongs to the Musgrave family) by Col. de Villamil, to whose industry and perseverance we owe the unravelling of the mystery of Newton's library. He also discovered at Somerset House a complete inventory of Newton's 